\title{
Biological Test of Formulation of Subculture Helicovepa armigera Nuclear Polihedrosis Virus (HaNPV) on Mortality of Spodoptera litura Larvae infested to cabbage (Brassica oleracea Var. capitata Linn.) Plantation
}

\author{
Desy Efriyani Anggraeny Nasution ${ }^{1}$, Mia Miranti $^{2}$, and Melanie ${ }^{3}$ \\ ${ }^{1)}$ Student. ${ }^{2)}$ Lecturer. ${ }^{3)}$ Lecturer. Biology, Faculty of Science, Universitas Padjadjaran \\ author: desyefriyanianggraeny@gmail.com and miantariksa@gmail.com
}

\begin{abstract}
Helicoverpa armigera Nuclear Polyhedrosis Virus (HaNPV) is one of the biological agents that could be used for the development of organic farming in Indonesia. One of the organic agricultural food products which have high economic value is cabbage, HaNPV effectif to control the population of several species of insect pests, can be used instead of synthetic insecticides in agricultural development efforts of organic cabbage. HaNPV formulation can be used as a way to maintain the virulence properties of the virus and facilitate the storage and application. The preparation of subculture HaNPV formulations was in liquid, powders, cornstarch and talk carrier material. The design experimental was used randomized block design consists single factor (type HaNPV formulation consisting of powder formulations, liquid formulation, formulation in cornstarch, and talc formulation including water formulation without virus as a control), with eight replications. The results showed that all of the formulations of subculture HaNPV causing larvae mortality at range $97.4 \%-100 \%$. The highest mortality of larvae occurred in cabbage plants are protected by HaNPV carrier liquid and talk preparations by $100 \%$ each.
\end{abstract}

Keywords: Formulations Helicoverpa armigera Nuclear Polyhedrosis Virus (HaNPV), subculture, Spodoptera litura, Brassica oleracea Var. capitata Linn.

\section{INTRODUCTION}

Biological control use insect Pathogenic is one of alternative control plant pests. The use of biological agents can provide a lot of excesses, among others in tackling environmental problems and develop organic farming system (Organic agriculture). One of the products organic agriculture which has high economic value so much interested in Indonesia is to be cultivated cabbage (Brassica oleracea var. Capitata Linn.). weakness the cultivation of cabbage plant is how many organisms buggers plant such as Spodoptera litura (armyworm). Larvae of S. litura causing damage to range $12.5 \%-20 \%$ on cabbage (Hendra et al., 2003).

As a pest, S. litura still are controlled with insecticide chemical, which can cause environmental pollution and impact in the long term can lead to pest resistance. Helicoverpa armigera Nuclear Polyhedrosis Virus (HaNPV) is one of the biological agents that can be used as bioinsektisisda alternative the use of a more environmentally friendly and able to control insect pests. The results of field research carried out at the University of Padjadjaran garden experiment, showed that the mortality in S. litura reaches 100\% (Nasution, 2013).

Bioinsektisida can be formulated with a carrier material to share, it aims to preserve stability and the prevention of contamination virus during in storage. Formulating a biological agents, thing to considered that the carrier is not antagonistic, easily soluble in water, and is able to spread evenly throughout the surface of the plant (Putri, 2012). Formulation biological agents of a better in the form of wettable powder, because in addition to easy storage and application, effectiveness to stand in long time (Naratanan, 1987 In: Bedjo, 2005).

ISSN 2413-0877 (C) 2015 The Authors.

Published by KnowledgeE Publishing Services This is an open access article under the CC BY-NC-ND license (http://creativecommons.org/licenses/by-nc-nd/4.0)

Selection and Peer-review under responsibility of the 3rd ICBS-2013

Doi http://dx.doi.org/10.18502/kls.v2i1.237 
Research for the formulations of HaNPV is increasing, formulation can use water, powder, cornstarch, and talc. In this research a try some of the materials to used a carrier. This research aims to get the best HaNPV types of formulations with different carriers in causing mortality in S. litura on cabbage plants that were exposed

\section{MATERIALS AND METHODS}

The design experimental was used randomized block design consists single factor (type HaNPV formulation consisting of powder formulations, liquid formulation, cornstarch formulation, and talc formulation including water formulation without virus as a control), with eight replications. Experimental parameters measured were larvae mortality of S. litura for 20 days of observation. Research results then analyzed using Analysis of Variance (ANOVA), and if there are significant differences in outcome data, followed by Duncan's multiple range test on standard $5 \%$.

The first phase, HaNPV subcultures derived from cadaveric S. litura infected HaNPV dead. Virus suspension was obtained by using the method of Indrayani et al. (1993) which has been modified. Amount polyhedra of calculated using the haemositometer and the concentration of the virus using methods of Indrayani et al. (1993).

The second phase, the formulation of HaNPV is sharing the material carrier prepared in accordance with concentrations used, the $4 \times 10^{7} \mathrm{PIB} / \mathrm{ml}$ (liquid) and $4 \times 10^{7} \mathrm{PIB} / \mathrm{g}$ (powder). The third phase, preparation of cabbage plants with maintenance procedures for seed, planting, watering, weed, and fertilization.

The fourth phase, implementation of the research conducted on cabbage plants were 10 weeks old, then HaNPV formulation is given 12 hours before exposure larvae of $S$. litura. Mortality is calculated every day and treatment formulations done every four day, during the 20 days of observation.

\section{RESULTS AND DISCUSSION}

Results of statistical analysis indicates that treatment of spraying and spreading HaNPV formulations in liquid dosage form, powder, cornstarch and a talk on the larvae of S. litura very influential on on mortality (Table 1). All the preparation in the form of HaNPV formulations has the same level of effectiveness in causing mortality in larvae of S. litura (Table 2).

Tabel 1. Results of Analysis of Variance for S. Mortality litura in each treatment.

\begin{tabular}{cccccc}
\hline $\begin{array}{c}\text { Source of } \\
\text { diversity }\end{array}$ & $\begin{array}{c}\text { Degree of } \\
\text { freedom }\end{array}$ & $\begin{array}{c}\text { Sum of } \\
\text { squared }\end{array}$ & $\begin{array}{c}\text { Middle } \\
\text { Squared }\end{array}$ & $\begin{array}{c}\mathrm{F} \\
\text { Count }\end{array}$ & $\begin{array}{c}\mathrm{F} \text { Table } \\
5 \%\end{array}$ \\
\hline Repeated & 7 & 345,89 & 49,41 & & \\
Treatment & 4 & 10968,4 & 2742,1 & $120,565^{*}$ & 2,71 \\
Galat & 28 & 636,82 & 22,74 & & \\
General & 39 & 11951,1 & & & \\
${ }^{*}=$ Significant at $5 \%$ & & & & &
\end{tabular}

Table 2 it can be seen that the formulation of the virus in carrier have the same ability in protecting the stability of the virulence of the virus it carries. Duncan's Multiple Range Test results indicates that can HaNPV control population of S. litura on cabbage plants that were exposed to causeing mortality at range $97.34 \%-100 \%$. 
Tabel 2. Duncan's Multiple Range Test results against S. Mortality litura on each treatment.

\begin{tabular}{cc}
\hline Treatment & Mortality in Larvae \\
\hline Control & $57,58 \mathrm{~b}$ \\
Powder & $98,21 \mathrm{a}$ \\
Liquid & $100 \mathrm{a}$ \\
Cornstarch & $97,34 \mathrm{a}$ \\
Talc & $100 \mathrm{a}$ \\
\hline a & Averagerent at $5 \%$ level
\end{tabular}

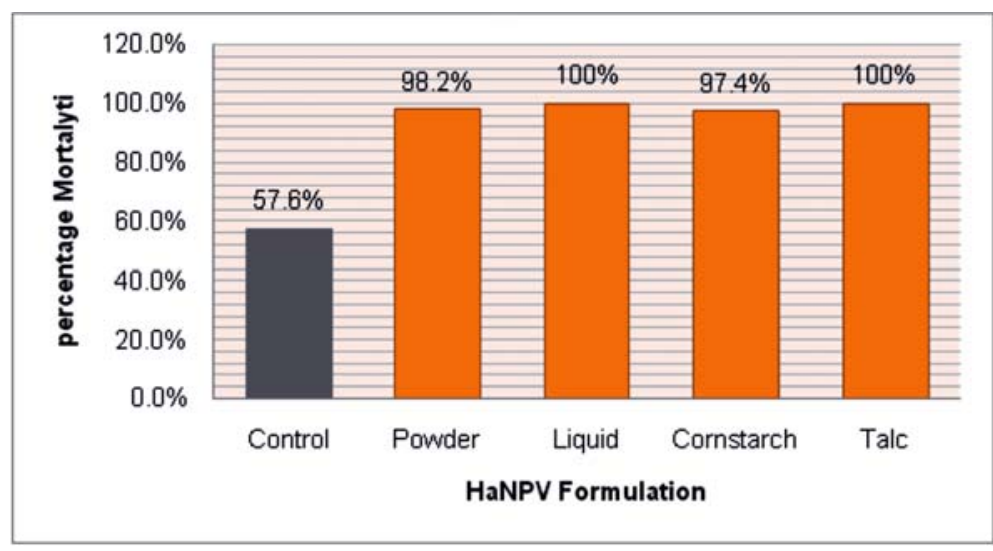

Figure 1. Percentage Mortality of $S$. litura on each treatment formulation HaNPV

Figure 1 indicates that the mortality of larvae of S.litura Highest litura resulting from the use of formulation HaNPV in liquid and talk with $100 \%$ each.

\section{ACKNOWLEDGMENT}

The authors wish to thank Dr. Mia Miranti, S.Si., MP and Melanie S.Si., M.Si as research supervisor.

\section{REFERENCES}

Bedjo. 2005. Potensi, Peluang dan Tantangan Pemanfaatan Spodoptera litura Nuclear Polyhedrosis Virus (SINPV) Untuk Pengendalian Spodoptera litura Fabricius Pada Tanaman Kedelai. Makalah Balitkabi.

Hendra, J.H. Laoh, and F. Puspita. 2003. Kerentaan larva Spodoptera litura Fabricius terhadap virus Nuklear Polihedrosis. Jurnal Natur Indonesia 5(2): 145-151

Indrayani, I.G.A.A., Subiyakto, dan G. Kartono. 1993. Teknik Perbanyakan Helicoverpa armigera Nuclear Polyhedrosis Virus (HaNPV). Prosiding Simposium Patologi Serangga. 12-13 Oktober 1993. UGM-Yogyakarta. 163-170.

Nasution, D.E.A. 2013. Uji Hayati Formulasi Helicoverpa armigera Nuclear Polihedrosis Virus (HaNPV) Hasil Sub-Kultur terhadap Populasi Spodoptera litura yang Didedahkan pada Tanaman Kubis (Brassica oleracea Var. capitata Linn.) Skripsi. Universitas Padjadjaran. Bandung. Tidak dipublikasikan.

Putri, R.K. 2012. Formulasi Sediaan Helicoverpa armigera Nuclear Polyhedrosis Virus (HaNPV) Hasil Subkultur Pada Spodoptera litura Fabricius Dalam Bahan Pembawa Air, Tepung Talk dan Tepung Maizena. Skripsi. Universitas Padjadjaran. Bandung. Tidak dipublikasikan. 